\title{
DURABLE OR TERMINAL? \\ Racial and ethnic explanations of the 2009 elections
}

\section{Thabisi Hoeane}

\author{
Dr Thabisi Hoeane holds a PhD in Political Science and is a \\ Senior Lecturer in the Department of Political Sciences, \\ University of South Africa \\ e-mail: hoeant@unisa.ac.za
}

\begin{abstract}
The perennial debate among academics, the media, analysts and the public in general, especially during election periods, is the level and extent to which racial and ethnic factors can be said to explain voters' behaviour in making their choices. There are two competing viewpoints. The first asserts that these two variables are primary in explaining voting behaviour, the second that they are of limited value in understanding electoral outcomes. The debate is significant as it is linked to and has an impact on the country's democratisation trajectory. The former viewpoint is generally negative, the latter relatively positive. The pessimistic view considers the voting patterns as necessarily imperilling democracy while the optimistic view posits that their existence in and of themselves does not threaten democracy as they have little agency in determining voters' choices. This article argues that race and ethnicity have had only a superficial effect on electoral outcomes from 1994 to 2009 and hence should not be accorded primacy in explaining the outcomes. An analysis of the 2009 elections provides tangible and incremental empirical evidence that their import and value as explanatory variables is weakening.
\end{abstract}

\section{INTRODUCTION}

In order to understand the complexity of South African politics - especially in relation to assessing prospects for the country's further democratisation - it is helpful to begin to recognise the superficiality of race and ethnicity and widen the debate to consider the influence of other electoral variables on voting behaviour. It is contended that this approach contributes to a deeper understanding of electoral outcomes and of prospects for the country's democratisation. 
The internalised and supposedly immutable racial and ethnic influences that are said to imperil democracy and, equally, the denialism embedded in rejecting the reality of race and ethnicity block the pursuit of other useful avenues for understanding and assisting the nurturing of democracy. This article focuses specifically on the successes of the Democratic Alliance (DA) in capturing the Western Province from the African National Congress (ANC), the efficacy of using concrete ideas to explain voting behaviour, the import of declining voter engagement and its utility in this debate, the significance of the establishment of the Congress of the People (Cope), the youth dimension and, finally, the 'Zuma/ Zulu' factor in KwaZulu-Natal.

\section{RACIAL AND ETHNIC INTERPRETATIONS OF THE 2009 ELECTIONS}

Electoral politics in South Africa are shaped by identities: Voters across the spectrum tend to remain loyal to parties that represent their identity group, defined by a complex mix of race, language and culture.

Friedman 2009

The good news is that Wednesday's general election was declared 'free and fair' by the African Union ... The bad news is that results show the enduring power of race in South African politics.

Saunderson-Meyer 2009

In this section the discussion focuses on the factors that have been identified as indicating that race and ethnicity are critical variables in an analysis of the 2009 election results and in an understanding of voter behaviour.

One of the factors cited to support the contention that race and ethnicity contributed significantly to voter behaviour and to the results of the 2009 elections is the racial support base of the political parties. South African political parties are still overwhelmingly supported by groups of clearly distinct racial backgrounds. In this regard, two major demographic groups are used to illustrate the point: 'black' political parties are still largely supported by black voters and, 'white' parties draw the majority of their support from the white community. For example, an Institute for Democracy in South Africa (Idasa) pre-elections briefing paper that analysed possible voting trends, quoting from a Plus 94 Research report, observed that the inquiry had revealed that '... party support in South Africa continues to be racially polarised. Black South Africans accounted for $75 \%$ of the ANC's support amongst respondents while white South Africans accounted for $71 \%$ of the DA support among respondents' (Sylvester 2009, p 5). 
This, it is posited, is clear evidence that the majority of the support for the governing party, the ANC, and the main opposition party, the DA, was drawn from particular racial groups, underlining the fact that the primary motivating factor behind voters' choices is identity. The significance of these support patterns, in the context of this racial-ethnic debate, is to indicate that despite 16 years of democracy party support and, consequently, the way voters make their decisions, are still governed by racial identities.

This view may also be gleaned from the way some party leaders construed - and understood the main motivation behind - contemporary South African voting behaviour. For example, in arguing for what she termed a need for voters to exercise their choice on the basis of political philosophies rather than on identity grounds, Helen Zille, leader of the official opposition, the DA, wrote in a media opinion piece in January 2009 that '[m]any South Africans still believe political choice is about race' (Business Day 19 January 2009, p 6). In Zille's view - and it should be noted that she is not the only politician who holds that view - South African voters still prioritise racial identity at the expense of other considerations. The thrust of Zille's argument is that it is imperative for voters to abandon these influences and embrace political philosophies such as that espoused by her party, which, she maintains, is based on an 'an open opportunity society for all' (Pahad 2009).

With regard to the question of ethnic choice, the view that voters are primarily driven by ethnicity in their choice of party was substantiated by the success of the ANC in decisively defeating, for the first time since 1994, the Inkatha Freedom Party (IFP) in KwaZulu-Natal. The ANC won 62.95 per cent of the vote to the IFP's 22.40 per cent. KwaZulu-Natal, the IFP's stronghold, is overwhelmingly 'Zulu' and the fact that the ANC defeated the IFP there so spectacularly may well be ascribed to the fact that its leader, Jacob Zuma, is a Zulu, a factor on which he capitalised, using it as the basis for challenging the IFP's monopolisation of the Zulu ethnic vote (Sithole \& Bramdaw 2009, pp 23-24). As one observer remarked: 'The ANC president, Jacob Zuma, with his grassroots appeal and celebration of his Zulu identity, played to ethnic sentiments' (City Press 3 May 2009, p 12).

Indeed, the argument is buttressed, quite ironically, by the IFP's own response, which suggested that the party agrees that Zuma 'out-Zulued' it. As Anthony Butler (April 2009, p 8) notes, the IFP accepted its defeat '... notwithstanding the complaint, from it of all parties, that Zuma had played the tribal card against it'. What Butler is illuminating is that the IFP, which considers itself the true custodian of 'Zuluness', was lamented the fact that the ANC had undermined this position because its leader is a ' $Z u^{\prime} \mathbf{u}^{\prime}$ '.

An interesting aspect of the resilience of identity interpretations of the 2009 election is the way identity is perceived to have affected the new party, the 
Congress of the People, in choosing its presidential candidate. Mosioua Lekota, who broke away from the ANC and was instrumental in forming Cope, was its interim leader. However, departing from South African electoral practice, in which party leaders are considered to be presidential candidates, Cope brought in Reverend Mvume Dandala, a civil society activist, to replace Lekota.

The reason for this unusual move has been given as the fact that Lekota had lobbied within party structures for support for the 'wrong' group - whites (Sowetan 24 February 2009, p 4). According to this analysis Lekota's publicly expressed misgivings about the continued use of race in implementing affirmative action and his contention that white South Africans, particularly Afrikaners, had been marginalised by the ANC government pitted him against his enemies within the party. It was believed that his views were strategically unsound and would alienate black voters from Cope (Sowetan 24 February 2009, p 4). This argument from Lekota's detractors was said to be based on the reality that the majority of South African voters are 'black'. Hence, those who intended to support Cope would be uncomfortable with a party that criticised affirmative action by being sympathetic to the interests of 'whites' and this would hurt the party at the polls.

The ethnic dimension and interpretation of this controversy was that Lekota was removed as the party's presidential candidate at the instigation of a powerful lobby group of 'Xhosa' leaders within Cope who wanted one of their own ethnic background to take over the mantle of the party (Mashele 2009). Indeed, one of Cope's leaders, Mlungisi Hlongwane, in resigning from the party and re-joining the ANC, released a media statement giving as the main reason for leaving Cope what he referred to as 'tribal tendencies' within the party, maintaining that 'It is regrettable that there are Xhosa speaking Cope leaders who have taken a conscious decision that Cope must be a predominantly Xhosa led organization' (www. politicsweb.co.za/ politicsweb/view/en/page71619?oid=1229).

The logic went thus: because Lekota is of 'Sotho' ethnic background a 'Xhosa' cabal within the party lobbied for Dandala, who is 'Xhosa', to be the party's presidential candidate.

In further relating the significance of these variables to an understanding of South African electoral politics political commentator Prince Mashele, of the Institute for Security Studies (ISS), asserted that despite the fact that it was acknowledged that Trevor Manuel was the best candidate for the presidency of the ANC, because he is 'coloured' and not ' black' he could not be elected to the position and, ultimately, become the country's president. Mashele also maintained that businessman and former unionist Cyril Ramaphosa was left out of the equation for the ANC leadership as his tribe [Venda] does not have significant numerical power within the ANC and the 'Zulus' felt it was their time to rule South Africa. 
The result of this line of reasoning is the conclusion that Zuma's ascendancy to the leadership of the ANC was primarily driven by ethnic factors at two levels: other 'ethnicities' were not strong enough to take up the mantle of leadership and 'tribal rotation' in ANC leadership and that of the country unofficially decreed that 'Xhosas' had to make way for 'Zulus' to assume power.

It is clear from the above that a racial and ethnic interpretation of South African elections and voter behaviour must still be applied to an understanding of the 2009 elections; parties' support bases are still racially based; leaders' conception of the motivations behind voter behaviour is informed by the notion that voters have not transcended identities in making political choices; 'Zulu' ethnic sentiments triumphed over any other explanatory variables, resulting in the ANC's successes in KwaZulu-Natal; Cope, a party that was thought to have ushered in trans-racial politics, has not been immune to the challenges posed by racial and ethnic identities; and some commentators are emphatic that identity politics still primarily defines and explains the contours of electoral politics in South Africa.

\section{THE COUNTER EVIDENCE}

But is racial and ethnic identity the only factor that motivates the choices of South African voters? This section argues that other influences must be considered.

\section{The Western Cape, 'Coloured voters' and the DA's victory in 2009}

It is a given in South African political analysis that the 'coloured vote' in the Western Cape is the fulcrum of electoral dynamics in that province in terms of determining which party wins at the polls. The influence of the 'coloured vote' cannot easily be discounted, but the argument that the numerical superiority of coloured people in the province means they constitute a unified voting bloc and make their political choices en masse can be challenged. The fact that, as Business Day (24 April 2009, p 1) reported, 'Hundreds of thousands of voters on the Cape Flats coloured areas such as Mitchell's Plain streamed out in record numbers to vote for the DA' does not justify the simplistic assertion that 'coloured voters' were racially motivated in their abandonment of the ANC.

Evidence would seem to suggest that far from signifying that they had abandoned a 'black' party for a 'white' party for racial reasons the fact that many coloured voters switched their support from the ANC to the DA was directly attributable to the $\mathrm{ANC}^{\prime}$ s disorganisation in that province prior to the election. That is, the party was in such disarray and so divided that it conducted an ineffectual campaign and could not convince 'coloured voters' to support it. 
Accordingly, it has been noted that ' $[t]$ he provincial gains that the ANC had made since 2004 - and there were several - on the other hand had been neutralised by controversy and perceptions of factionalism' (Hofmeyr 2009, p 19). Interestingly, the ANC itself also reached this conclusion, as reflected in an official report that ultimately led to the disbandment of the provincial party structure in the Western Cape (Mail \& Guardian 28 May 2009, p 15).

Thus, the preoccupation with factional infighting within the ANC in the Western Cape in the run-up to the elections had the effect of driving away 'coloured voters', who made their decision on a rational basis, not one founded on identity, for generally voters are unlikely to trust a party that does not inspire their confidence or is riven with internal problems to represent their interests effectively.

Apart from the reasons given above for its victory, the DA ran a very effective campaign, focusing its energies specifically on the Western Province, as evidenced by the fact that its leader, Helen Zille, stood as premier of the province rather than as a presidential or national candidate. As Hofmeyr (2009, p 20) observed in this regard, 'The DA made the Western Cape its area of focus and voters noticed it'.

Indeed, holistically, from 1994 through to 1999, 2004 and 2009 there have been shifts in the way 'coloured' voters have supported different political parties in the province, challenging the notion that they are locked in rigid racialised sentimental voting patterns. In 1994 they voted overwhelmingly for the National Party (NP) and in 1999 and again in 2004 for the ANC. These swings between 'black' and 'white' parties seriously challenge the racial view that they are an homogenous bloc primarily motivated by racial considerations; immutable and not susceptible to change.

On the contrary, it would appear that at election time 'coloured voters' make decisions related to their specific interests. They placed their faith in the NP in 1994, moved to the ANC when the NNP floundered in the run-up to the 1999 election and abandoned it in 2009 because it no longer appeared to cater for their needs.

Another factor that accounted for the DA victory in the province in 2009 can be ascribed to Zille's political acumen. It is a tricky enterprise to try to fathom to what extent political personalities ultimately influence voting decisions but it can be deduced that some do and that Zille proved to be one of them. In its postelection analysis of the Western Cape provincial elections the Mail \& Guardian (29 April 2009, p 4) was forthright about this point: 'More than any other factor the massive swing to the DA - it took $27 \%$ in 2004 - should be put down to the personality and public clout of party leader Helen Zille.'

Viewed from another perspective, the Western Cape result emphatically challenges the view that the DA is a 'white English-speaking party'. For it is in this province that the DA has been able to dislodge the ANC from power, not 
because of the strength of white voters but because of coloured and, indeed, marginally, black voters.

The results clearly show that the days of the DA as a stuffy party of English- speaking whites are over. Zille's re-orientation of the party towards a racially inclusive message and image enabled her to make inroads into the African vote and reverse ANC gains in past elections in the Western Cape's rural hinterland.

Joubert 29 April 2009, p 4

The historical reality that the coloured people in the province are not wedded to one political party indicates that to ascribe emotive and racialised explanations to the behaviour of 'coloured voters' in the Western Cape is to limit analysis.

South African political parties are defined as being racial purely on the basis that their support is primarily based on race. Hence, the ANC is considered to be 'black', the DA 'white' and the Minority Front 'Indian'. What is immediately striking, and missing from this categorisation, is that there has never been a 'coloured' party in post-apartheid South Africa. Therefore, the question that needs to be considered is why the third-largest of South Africa's racial groupings does not feel the need to form a party. This question would be particularly relevant in the Western Cape, where people designated as coloured form a sizeable majority of the voting population to the extent that there is a specific 'coloured' vote. Taken to its logical conclusion then, if political cohesion is deeply ingrained in other South African racial groups why is it absent from the 'coloured' group? The answer is that no single racial solidarity factor impels them to form a distinct political organisation. They vote for political parties according to their interests and inclinations, hence they were able to vote for the 'black' ANC in 2004 and for the 'white' DA in 2009.

The conclusion that can be derived from this is that there is no homogenous 'coloured' voting bloc and the 'coloured' population has no need to form a political party since its political interests are represented by other parties. If we recognise the racial/ethnic view that the 'coloureds' are a 'swing vote' in the Western Cape and their motivation to vote for either a 'black' or a 'white' party is not based on race what should be considered is what variables are at play here to explain their voting motivations.

\section{The utility of ideas}

A pre-elections Plus 94 research survey noted that ANC voters are mainly attracted to the party because they believe it will provide them with housing and social 
grants, while the main motivation for aligning with the DA and Cope is a desire for 'change' (Sunday Times 29 March 2009, p 4). This indicates that ANC policies, which emphasise the provision of social services, are the main attraction for black voters - the majority of whom still need such assistance - and thus that they support the ANC not because it is a 'black' party but because of its commitment to the transformation of society, which is underpinned by the provision of services which have an impact on the lives of the poor. It is therefore not surprising that most of the ANC's supporters are black, given that the majority of South Africa's poor, thanks to the legacy of apartheid, are black.

On the other hand, the DA's and Cope's espousal of the message of 'change' and their argument that the ANC has abused its powers, has been unaccountable and corrupt and has blurred state and party functions is attractive to the middle and upper classes across the racial spectrum. These factors undermine the racial and ethnic theory. Furthermore, in their campaigns these major South African political parties do not make their pitch to voters on the basis of race or ethnicity, but on what they will concretely offer.

Despite the above observations crude and unsubstantiated racial analysis of parties' political campaigns persist. For instance, the DA's campaign battle cry, 'stop Zuma' was, in some quarters, taken to have racist undertones, with, for example, Alan Boesak, Cope leader in the Western Cape, charging that, 'Cheap rhetoric that smacks of racist undertones, playing the man and not the policy, welcome to the world of the DA, a party infused with apartheid-style politics which has no place in our country' (www.iol.co.za/news/politics/boesakattacks-da-stop-zuma-ccampaign-1.440074). But this is a superficial and, indeed, a disingenuous interpretation of the focus of that campaign. For nowhere does the press statement released by Zille in announcing the campaign mention Zuma's race - it focuses on what the DA construes Zuma to represent: an ANC leadership that will undermine the Constitution and threaten press freedom and the judiciary, and so on (www.org.za/newsroom.htm?action=view-news-item\&id=6620). Thus, in the DA's view Zuma was merely the symbolic embodiment of what was wrong with the ANC and Boesak's racial charge was without foundation or credibility.

\section{DECLINING VOTER ENGAGEMENT}

Although interest in South African elections has remained high among voters, as indicated emphatically by the high voter turnout in successive elections and voter registration in 2009, there is incremental evidence that, overall, voters are increasingly disengaging. Although those voters who do register are enthusiastic about participating there has been an overall decline in the number of voters who go to the polls in each election. In 1994, 19 million of an estimated 22 million voters 
(there was no voters' roll in this election) cast their votes (a turnout of 86.9\%); in 199916 million of a registered 18 million voted ( $89 \%$ ); the figures in 2004 were 15 million of 20 million (76 \%) and in 2009, 17 million of 23 million (77\%).

Reasons for the lack of interest in elections can be classified broadly in two categories: those who are apathetic and negative, having lost hope, for whatever reason, in the political process, and those who are content that democracy is on the right path so they feel no need to participate.

If the former is the primary reason racial and ethnic explanations face serious difficulties. The logical consistency of the racial/ethnic interpretation is that it would be easy, and indeed a compelling choice, for voters to vote for existing 'racial/ethnic' parties given their affinity to the racial and ethnic backgrounds. For, if existing parties do not attract a significant portion of voters how is the view sustainable that voters are moved by passionate racial and ethnic sentiments in making their party choices. Which necessitates the following rhetorical question: what, then, motivates these despondent voters not to vote for existing parties when it is argued that they have an intrinsic attraction? Clearly the answer must be sought elsewhere - that they feel that existing South African political parties do not reflect their interests, whatever those might be. On this basis, therefore, racial and ethnic interpretations fall short.

\section{THE SIGNIFICANCE OF THE FORMATION OF COPE}

One of the most significant political occurrences in post-apartheid South African politics has been the formation of the Congress of the People. Firstly, for the first time since 1994 the ANC faced a significant split, which led to the formation of this party by senior and credible leaders and ANC stalwarts such as former Gauteng premier Mbhazima Shilowa and former Defence Minister Mosioua Lekota. The significance of this development was that potentially the ANC, for the first time since 1994, was facing a formidable challenge to its power. And indeed, the uniqueness of Cope is that unlike many new parties it performed very strongly, if not exceptionally, becoming the third-largest party in the country after the elections, winning more than a million votes. Very significantly, Cope is the official opposition in five provinces, meaning that it has more widespread support nationally than the DA, despite the fact that it was less than a year old by the time of the election and was riven by serious internal problems.

The import of the emergence of Cope to the racial/ethnic interpretation is that it is highly questionable that those who voted for it are intrinsically tied to their parties by race and ethnicity. If that were the reality, why was it possible to have this seismic shift, with so many voters placing their faith in Cope? Does the emergence of Cope not signify that, indeed, there is a new politics emerging 
in South Africa which goes beyond race and ethnicity? It is, of course, early and it would be perilous to give a definite answer at this juncture. But it is also safe to point out that there is a ray of hope that the emergence of Cope signifies a maturing of South Africa's democracy, which trumps the assertion that race and ethnicity underlie the country's politics

Analysis indicates that the success of Cope, far from being an expression of racial and ethnic sentiment, can be ascribed to other variable. For example, Ndletyana (2009) and Piper \& Matisson (2009) have argued that the main driving force of the intensive and fractious debates that preceded and took place during the ANC's Polokwane conference, which ultimately led to the formation of Cope, can be best understood through the prism of ideological differences within the ANC not racial/ethnic motivation. In this regard, therefore, the split within the ANC and the subsequent formation of Cope can be ascribed to concrete ideological realities rather than to emotive identity politics, once again straining the emphasis of the former as driving South African politics, especially its electoral processes.

\section{THE YOUTH DIMENSION}

One enduring trait of post-1994 South Africa has been the extent to which the youth have been considered to be apathetic and indifferent to political processes such as elections. The abiding interpretation of the phenomenon is that in a democratic South Africa the youth have interests over and beyond politics; that they are the 'born free', who have little to do with the pre-1994 political contestation. This observation is, to a large extent, based on reality, although it is not absolute. The 2009 elections, however, indicated that is changing and there has been an unprecedented upsurge in youth interest in the elections in terms of intention to vote.

In the last registration drive held by the Independent Electoral Commission (IEC), in February 2009, a staggering 73 per cent (1 099 519) of total new registrations (1 505 642) were young people aged between 18 and 29 (IEC 2009).

The relevance of this youth interest to the debate is that in and of itself this phenomenon presents formidable challenges to the racial and ethnic assertions. For it should be explained what particularly attracted the youth to participate in such numbers in this particular election? Can this in any way be linked to identity politics? Or are there other explanations that would shed light on this sudden surge in youth interest? The latter interpretation should take precedence on many grounds. First, arguably the 2009 election campaign was bereft of any overt racial/ethnic issues, with parties focusing on other matters relevant to the electorate such as jobs, corruption and so on. This is in contrast to, for example, the 1999 elections, which were laced with acrimonious racial campaigning. On this 
basis it can be argued that the claim that elections hold a racial/ethnic attraction for the youth can be dismissed out of hand.

In that case, what stoked this interest? One of the explanations is that the 2009 election was one of the most highly contested in post-apartheid South Africa, with the emergence of Cope and its potential to challenge the ANC, the DA re-envisioning itself as a post- racial party and the highly contested political terrain that informed the election, such as Jacob Zuma's legal problems and his prominence as a political leader and the ousting of Thabo Mbeki at Polokwane and his subsequent dismissal as the country's president by his own party.

All these issues ignited serious interest, which touched the youth as well. On this basis, therefore, it can be surmised that young people became interested in the election in order to make their mark on society, a conclusion that challenges the view that race and ethnicity are the primary determinants informing political participation. The fact that the country was dealing with critical issues drew this significant section of society into the centre of politics, not identity, showing that other variable can and should be used to explain the motivation for political participation. The youth wanted to be heard - not because of their racial/ ethnic backgrounds but because the issues involved had a direct impact on their lives as citizens.

\section{ZUMA AND THE ‘ZULU’ FACTOR IN KWAZULU-NATAL}

The argument that Jacob Zuma, in a move unprecedented for an ANC leader, fully exploited his Zulu identity has some validity. This is reflected in the observation of Sithole \& Bramdaw that 'Zulu royalty including the Zulu Monarchy takes pride in the fact that a Zulu will, for the first time in 15 years of our democracy be in charge of the country. This was evident in the public appearances and meeting Zuma held with the Zulu monarch King Goodwill Zwelithini, on the evening of the Polokwane conference' (Sithole \& Bramdaw 2009, p 23). Thus Zuma's Zulu factor is linked to the ANC's success in KwaZulu-Natal, as significantly pointed out by Habib (2009, p 12): 'The ANC lost electoral support in all provinces except KwaZulu-Natal. In the latter its electoral support jumped by a massive 943,481 votes from $47.7 \%$ in 2004 to $63.97 \%$ in 2009.' The argument thus flows in the following manner: for the first time the 'Zulu' electorate had one of their own leading the ANC, hence the 'Zulu' IFP had a serious rival, leading it to lose the election. Deductively, this might arguably marginally be so, but to what effect and to what extent can it be the primary reason for the ANC's success in KwaZuluNatal?

One flaw in this argument is the overarching, and usually uncritically considered, perception that the IFP has always been the dominant party in 
KwaZulu-Natal politics. The evidence points in a different direction. Even before 1994 KwaZulu-Natal was one of the provinces most politically contested by allies of the ANC and the United Democratic Front (UDF) and the then Inkatha, as unfortunately evidenced by the serious political violence that racked the province. The argument would therefore be that the IFP has never had the untrammelled support of 'Zulus' in the province. Indeed, electorally, since 1994 the IFP had been gradually losing whatever power it had mustered among 'Zulu' voters. In 1994 it narrowly won the province with 50.32 per cent to the ANC's 32.32 per cent; in 1999 its support fell to 41.90 per cent to the ANC's increased 39.38 per cent; in 2004 it lost the province to the ANC with 36.82 per cent to the ANC's 46.98 per cent and, in 2009, the ANC won its resounding victory, with 63.97 per cent to the IFP's 22.40 per cent. So, incrementally, since 1994 the power of the IFP has been waning in KwaZulu-Natal without the influence of the 'Zuma/Zulu' factor.

Thus, to the extent that Zuma's 'Zuluness' can be ascribed any force in the 2009 elections it is emphasised by tilting the balance spectacularly in favour of the ANC in what was already a process in motion. The import of this analysis is that other factors should be taken into consideration. One element that militates against this 'Zuma factor' is the fact that, by most accounts, the ANC, since it assumed control of the province in 2004, has made serious inroads into IFP rural strongholds because of its efficient management of service delivery in the province. Sithole \& Bramdaw (2009, p 24) observe that:

Service delivery played a huge role in winning support for the ANC. Most KZN government departments embarked on service delivery and developmental programmes which targeted the province's rural communities between 2004 and 2009 ... Although IFP leader Buthelezi has often warned his councillors against the lack of service delivery, it remains that IFP-controlled councils are amongst the worst performing in KZN.

Thus the ability of the ANC provincial government to deliver on its promises and the IFP's failure to deliver on its overshadowed the ethnic interpretation in that rural Zulu voters had the evidence before their eyes that the ANC could deliver and they deserted the IFP. The import of this is that there is a problem with analyses that assume that the fact that the IFP's home base is in KwaZuluNatal, where most of its members are located, means the party was dominant in that province. The above evidence, that other considerations came into play, refutes this assumption.

Indeed, the internal logic of the racial/ethnic view is that the ANC is a 'Xhosa'-dominated party rooted in the Eastern Cape province. Taking this 
perspective into consideration it would not have been beyond the realms of possibility that in the 2009 elections, with the ANC being led by a ' $Z u l u$ ', there would have been a backlash of Xhosa voters in the Eastern Cape that would have resulted in them in abandoning the ANC in droves. However, this did not come to pass, indicating that although the ANC marginally lost support in the Eastern Cape this was not the result of any 'Xhosa' backlash. If anything, the erosion of support for the ANC in the Eastern Cape can be explained in terms of the emergence of Cope and the failure of such parties as the United Democratic Movement, which, although once very strong in that province, lost half its support in 2009 (Hoeane 2009, p 172).

Ironically, the view that the ANC is dominated by 'Xhosa' and is rooted in the Eastern Cape suffers from the same deficiencies as the contention that the IFP's stronghold has always been in KwaZulu-Natal. The reality is that very significant numbers of card-carrying members of the ANC are from the Eastern Cape and can hence be classified as 'Xhosa', but they do not constitute the majority of ANC members countrywide. Indeed, in general terms, there is no indication that the fact that the ANC is led by a 'Zulu' has had any effect on its power in other provinces. The party's electoral support has declined marginally in each province, except, of course, in KwaZulu-Natal, and the analysis of this decline is not pinned on the ethnic factor.

The apparent paradox in this regard is that it is only in KwaZulu-Natal that the ethnic (Zulu) factor is considered to have played a role, whereas the ANC's marginal decline in other provinces is ascribed to other considerations. For consistency of analysis it would appear that the ethnic interpretation in KwaZulu-Natal is skewed, as it is applied selectively. This evidence affirms that for ANC supporters and voters the ethnic background of the party's leader is not relevant.

\section{CONCLUSION}

The fact that racial and ethnic patterns can be discerned in South African elections, as they were in 2009 , is not irrefutable proof that these identities are primarily responsible for voting behaviour. It is undeniable that such concerns might motivate some voters but the issue to confront is the fact that it is necessary to take other variables into account in order to gain a comprehensive understanding of the motivations of voters.

These include factors such as material reasons for choosing parties, voters' assessment of the performance of parties, and the role and attraction of political leaders. Merely ascribing voting behaviour to emotive identity considerations does not address the bigger picture. Indeed, to assist the democratic consolidation 
of South Africa it is imperative that social scientific research engages in this endeavour and moves beyond the superficiality of race and identity because, as explanatory variables, they fall short.

\section{- REFERENCES -}

Butler, A. 2009. 'Several reasons for SA to bask in post-election glow'. Business Day, 28 April.

Ensor, L. 2009. 'Zille for premier in Cape as DA claims majority'. Business Day, 24 April.

Friedman, S. 2009. “'An Accidental Advance?" South Africa's 2009 Elections'. Journal of Democracy 20(4), October.

Habib, A. 2009. 'South Africa's 2009 Elections'. The Thinker, May.

Hoeane, T. 2009. 'Eastern Cape'. In K Matlosa (ed). Election Update South Africa February'. Johannessburg: EISA.

Independent Electoral Commission. 2009. 'Registration Activity 7 \& 8 February 2009'. Pretoria: IEC.

Hofmeyr, J. 2009. 'Western Cape Analysis'. The Thinker, May.

Joubert, P. 2009. 'W Cape does the Zille Swing'. Mail \& Guardian, 29 April. .2009. 'Axe hovers over W Cape ANC'. Mail \& Guardian, 28 May.

Lekota, I. 2009. 'Racial Slant costs Lekota Major Post'. Sowetan, 24 February.

Mashele, P. 2010. 'Voting along tribal lines'. Available at: www.news24.com/ columnists / Prince Mashele/ voting-along-tribal-lines-20090316

Ndletyana, M. 2009. 'Cope: The beginning of the resolution of ideological contestation within the African National Congress'. Paper presented at the College of Human Sciences Unisa, 29 July.

Pahad, E. 2009. Interview with Helen Zille. The Thinker, April.

Piper, L \& H Matisson. 2009. 'Democracy by Accident: The Rise of Zuma and the Renaissance of the Tripartite Alliance'. Representation 45(2).

Saunderson-Meyer, W. 2009. 'Forward to the past'. The Citizen, 25 April.

Sithole, J \& N Bramdaw. 2009. 'KwaZulu Natal Analysis'. The Thinker, May.

Sylvester, J. 2009. 'Opposition Performance at the polls in 2009'. Idasa Election Brief 2009. Cape Town: Idasa.

Wosu, A. 2009. Letter. City Press, 3 May.

Zille, H. 2009. 'The real choice for SA voters'. Business Day, 19 January. 